\title{
Geographic distribution of two mussel species and associated assemblages along the northern Argentinean coast
}

\author{
L. P. Arribas ${ }^{1, *}$, M. Bagur ${ }^{1}$, E. Klein ${ }^{2}$, P. E. Penchaszadeh ${ }^{1}$, M. G. Palomo ${ }^{1}$ \\ ${ }^{1}$ Museo Argentino de Ciencias Naturales ‘Bernardino Rivadavia' (CONICET), Av. Ángel Gallardo 470, C1405DJR, \\ Buenos Aires, Argentina \\ ${ }^{2}$ Laboratorio de Sensores Remotos e Instituto de Tecnología y Ciencias Marinas, Universidad Simón Bolívar, Caracas, \\ Miranda, Venezuela
}

\begin{abstract}
Ecosystem engineers can modify habitat, creating structural microhabitats. This structural complexity can affect species richness. Marine ecosystem engineers are able to produce local effects in combination with environmental variables (e.g. to create more humid habitat during low tides). We tested the hypotheses that if there is a relationship between mussel morphology and environmental factors, mussels would be larger at warmer than at cooler locations, and in areas where 2 species of mussels overlap, size and biomass will decrease and density will increase. At a smaller scale, we predicted that there is a relationship between the assemblage structure and hardness of the substratum and sediment content of a mussel bed. Using a nested design, we measured density, biomass and size of 2 species of mussels, Brachidontes rodriguezii and Perumytilus (Brachidontes) purpuratus, and diversity of species associated with mussel beds at 2 rocky intertidal sites at each of 4 shores along the northern Argentinean coast. These variables were correlated with oceanographic conditions and local characteristics. Significant correlations were found between intertidal assemblages and local factors. The largest specimens of $B$. rodriguezii and $P$. purpuratus were found at the warmer shores. In areas where they overlapped, size, biomass and density of $P$. purpuratus were lower, although $B$. rodriguezii did not change. The mean abundance of invertebrates associated with a mussel bed showed significant differences among shores. These 2 species of mytilids coexist over a small area, and although these species are very similar in their biological and ecological function, the fauna associated with their matrices are very different.
\end{abstract}

KEY WORDS: Spatial variations $\cdot$ Rocky shores $\cdot$ Ecosystem engineers $\cdot$ Environmental factors · Benthos · Southwest Atlantic

\section{INTRODUCTION}

To understand processes operating at different spatial scales and how they generate patterns in natural communities has become a central focus in ecological research. Studies on rocky intertidal shores have explained the role of predators in the distribution of organisms in the inferior limit of the intertidal region (Connell 1961, Dayton 1971, Menge 1976). Paine (1966) investigated how the interspecific com- petition for space affects the relative abundance of species, and Bertness (1989) discussed facilitation. Menge et al. (1997) found that nearshore primary productivity levels control differences in rocky intertidal community structure. These studies have been very important for understanding the processes that shape the rocky intertidal communities.

Intertidal zones experience large changes over the daily tidal cycle, with higher shore elevations having longer periods of immersion and greater exposure to 
physically harsh conditions (Murray et al. 2002). In addition, local meteorological conditions such as wind, precipitation and climate anomalies can cause large impacts on ecosystems (Mantua \& Hare 2002). The species that live in these habitats survive in variable and sometimes extreme physical conditions. One factor that correlates well with the abundance and diversity of species is water temperature, particularly over latitudinal gradients (Rohde 1992). Many other factors also correlate with species distributions and patterns of abundance (e.g. physical interactions between organisms and their habitats, behavioural and physiological adaptations; Burrows \& Hughes 1989).

Changes in the structure of assemblages of intertidal species at the scales of hundreds of kilometres and hundreds of metres may be attributed to differences in topography, substrate type, hydrodynamic conditions, intertidal elevation, wave exposure, climatic differences or variation in primary productivity (Araujo et al. 2005, Liuzzi \& López Gappa 2008, Burrows et al. 2009). Spatial variability at the scale of tens to hundreds of metres along shores is mainly a consequence of differences in recruitment and/or mortality as well as topography and elevation (Underwood \& Chapman 1996, Bownes \& McQuaid 2009). At the smallest spatial scale, such differences can be explained by a random scattering of suitable microhabitats and behavioural processes in species with limited adult dispersal (Underwood \& Chapman 1996). For example, in Oregon (USA), barnacles such as Balanus glandula, which are dominant in the high intertidal zone, reduce population sizes of subordinate adults by increasing the rate at which the barnacles settle on and kill subordinates (Connolly \& Roughgarden 1998). This could explain the replacement of one species by another along a shore, since larvae that successfully return to shore could compete and cause a decrease in abundances of other species by increasing mortality and decreasing the available substrate.

In coastal hard substrate habitats, sessile plants and animals cover most of the surface and could be important in structuring the associated invertebrate assemblages (Tsuchiya \& Nishihira 1985, Prado \& Castilla 2006). Some species can modulate the availability of resources by the creation of structural microhabitats that could facilitate other species (i.e. ecosystem engineers, Jones et al. 1994, 1997). Modification of the physical environment may have cascading effects on associated fauna (Badano \& Marquet 2008, Cole \& McQuaid 2010). At a landscape scale, species richness and abundance of generalist taxa are increased by the facilitation activity of mus- sel species, through production of shells that introduce complexity into benthic assemblages (Gutiérrez et al. 2003, Borthagaray \& Carranza 2007, Palomo et al. 2007). Given the extreme physical and weather conditions that an organism may tolerate in the intertidal zone, the expectation is to find greater diversity of species in areas associated with the presence or activity of ecosystem engineers than in areas without them. On rocky intertidal shores, the complex structure of mussel matrices provides refuge from thermal stress and traps fine-grained sediment and organic particles, favouring occupancy by small animals by creating habitat that is much cooler and more humid than elsewhere during low tides. Mussels can also provide space for algae and epifauna to settle and better protection from predators (Tsuchiya \& Nishihira 1985, Prado \& Castilla 2006, Cole 2010). Nevertheless, in some cases, invasive engineers may decrease species diversity by changing habitat complexity and by replacing more heterogeneous native assemblages (Crooks 2002, Hastings et al. 2007).

Nearshore oceanographic conditions have been shown to determine community structure along the coast (Menge et al. 1997, Blanchette et al. 2006) such as influencing larval delivery, which in turn affects community structure. Environmental and/or physiological stress periods could reflect an irregular shell growth break period in which shell deposition is interrupted (Richardson 2001). Annual shell growth rates in many bivalves are related to sea surface water temperature (SST) (Jones 1981), but sizes can also vary due to differences in longevity, rates of predation (Peacor et al. 2007) or environmental stresses other than temperature.

We examined the scale-dependent population size structure patterns and abundance of the mussels Brachidontes rodriguezii and Perumytilus (Brachidontes) purpuratus as well as the range-edge dynamics of these 2 bioengineer species, which potentially modify the diversity and structure of the associated assemblages. In addition, we studied whether assemblage structure is influenced by oceanographic conditions (e.g. SST) and local effects (e.g. hardness of substratum) along 4 degrees of latitude. Because marine ecosystem engineers are able to produce local effects in combination with environmental variables, we evaluated different hypotheses at different spatial scales. At the scale of hundreds of kilometres, we predicted that there would be associations between structure of assemblages and SST and chlorophyll a ( $\mathrm{chl}$ a) concentration. The average length of mussels increases with temperature (Blanchette et al. 2007); therefore, we hypothesized that mussels 
would be larger at the northern sites where it is warmer than in the south. Furthermore, in areas of overlap, some interspecific competition would be expected. Competition could affect abundance and growth rates of mussels (Blanchette \& Gaines 2007). We hypothesized that in areas where $B$. rodriguezii and $P$. purpuratus overlap, sizes and biomasses would be smaller and densities greater than in areas at similar latitudes where they occur by themselves. We hypothesized that a detriment in size generates more available substrate per square metre and as a consequence, an increase in mussel density. We further hypothesized that different assemblages of invertebrates would be associated with beds of different species of mussels. At the scale of hundreds of metres, we predicted that there would be a relationship between the assemblage structure, substratum hardness and sediment content of the matrix, assuming that the hardness of the substratum generates differences in mussel structure as soft sediments are less stable and more susceptible to erosion than hard ones. Understanding the variation among invertebrate assemblages associated with intertidal rocky shores at different spatial scales will provide crucial information about the importance of different factors that might be associated with these assemblages and the way they might interact (Underwood 2000).

\section{MATERIALS AND METHODS}

\section{Study area}

The present study was carried out along the northern shores of Argentina from $38^{\circ} 01^{\prime} \mathrm{S}$ to $41^{\circ} 43^{\prime} \mathrm{S}$. Brachidontes rodriguezii is the dominant species in the north of the Argentinean coast down to $41^{\circ}$, where B. rodriguezii and Perumytilus purpuratus coexist (Adami et al. 2004, Bertness et al. 2006, Prado \& Castilla 2006). In the coastal area of Mar del Plata (Buenos Aires province) sandy beaches alternate with quartzitic outcrops and abrasion platforms, with a microtidal regime (Elías et al. 2003). The coastal area in Río Negro province consists of sandy, gravelly strips in northern regions and rocky volcanic outcrops in southern regions (Kokot et al. 2004). This province has a macrotidal regime with cliffs and sedimentary abrasion platforms that alternate with sandy beaches. The average tidal range in Buenos Aires is $\sim 0.8 \mathrm{~m}$ with a yearly maximal range of $1.6 \mathrm{~m}$, while in Río Negro the range is $\sim 4 \mathrm{~m}$. The sampled shores were Mar del Plata (381' 26.04" $\mathrm{S}, 57^{\circ} 31^{\prime} 37.96^{\prime \prime} \mathrm{W}$, hereafter MDQ), La Lobería (41ํ' $9^{\prime} 19.32^{\prime \prime} \mathrm{S}, 63^{\circ} 7^{\prime} 26.24^{\prime \prime} \mathrm{W}$, hereafter LO),
Playa Los Suecos (4140'6.52" S, 65²1'33.31" W, hereafter PS) and Punta Colorada $\left(41^{\circ} 42^{\prime} 7.20^{\prime \prime} \mathrm{S}\right.$, 65 1' 22.65" W, hereafter PC; Fig. 1).

\section{Sampling}

To test whether oceanographic conditions and local characteristics affect the structure of the mussel beds and their related assemblages, we sampled 4 rocky shores along $900 \mathrm{~km}$ of coastline between 4 and $570 \mathrm{~km}$ apart. Each shore (MDQ, LO, PC and PS) included 2 sites between 100 and $500 \mathrm{~m}$ apart and 4 replicate cores 1 to $3 \mathrm{~m}$ apart from each other. Samples were collected at the mid-intertidal level by scraping out the contents of a core $(10 \mathrm{~cm}$ diameter) placed in the mussel bed. Samples were stored in $96 \%$ ethanol; organisms $>0.5 \mathrm{~mm}$ were identified and counted. The sediment trapped in the mussel matrix was collected with the core, dried, sorted and weighed. Sediment was sieved through a series of 6 different mesh sizes from 2000 to $62 \mu \mathrm{m}$, and sediment size was expressed according to the phi scale (Gray 1981).

The mussels were dried $\left(70^{\circ} \mathrm{C}\right.$ for $\left.72 \mathrm{~h}\right)$ to a constant weight to calculate biomass $\left(\mathrm{B}, \mathrm{g} \mathrm{m}^{-2}\right)$. For individuals $>5 \mathrm{~mm}$, shell lengths of 50 individuals in each replicate core (when possible) were measured to the nearest $0.01 \mathrm{~mm}$ using callipers. Mussel length measurements were pooled (from the 4 cores in each site) for each shore, according to species, so

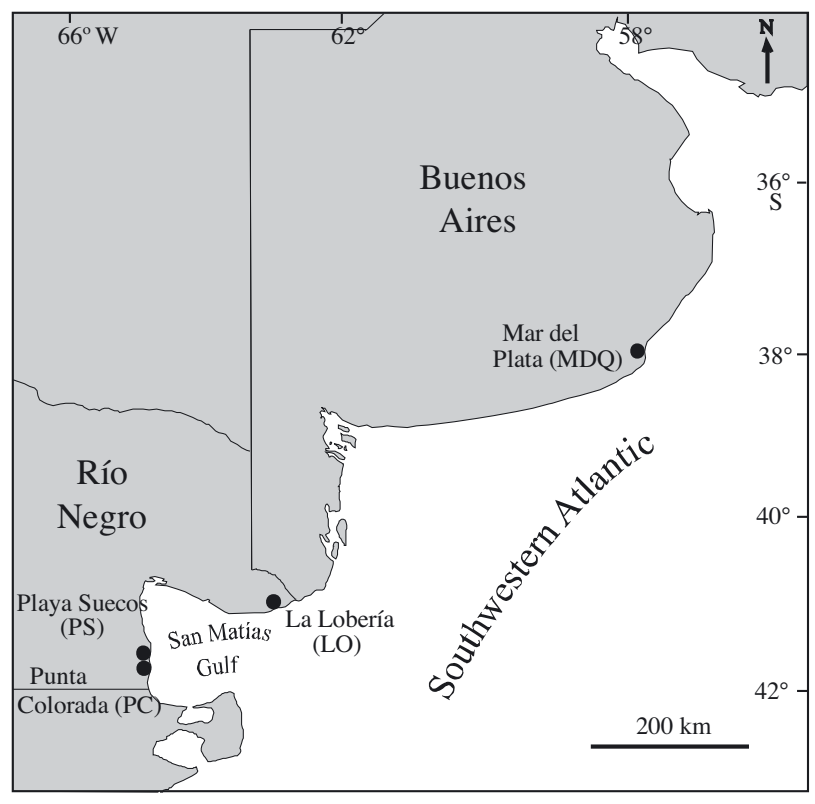

Fig. 1. Shores sampled on the Argentinean coast and corresponding abbreviations 
that size frequency distributions of mussel populations could be assessed visually.

To test whether species diversity differs between samples containing different mussel species (Brachidontes rodriguezii vs. Perumytilus purpuratus), samples were sorted using a stereoscopic microscope and all organisms were identified to the lowest taxonomic level possible. The total number of species, Shannon-Wiener diversity index $\left(H^{\prime}\right)$, Pielou's evenness $\left(J^{\prime}\right)$ and abundance were calculated for each sampling unit. Algae species were only included in the total number of species as they were only measured in terms of presence/absence.

To test whether substratum hardness is associated with the structure of intertidal assemblages, hardness was first assessed by drilling into the rock with a power drill for a fixed period of time $(6 \mathrm{~mm}$ drill bit for $10 \mathrm{~s})$. Depths of the holes $(\mathrm{n}=3)$ at each site were measured with callipers to the nearest $0.01 \mathrm{~mm}$. Mean depth was converted to an index of hardness using its reciprocal value. A hardness scale was established from the results of the drilling experiments. The softer rock (LO in this study) was arbitrarily assigned a hardness of 1.0. The scale consisted of the ratio of depth of penetration for LO rock to depth of penetration in other rock (see Evans 1968, Pinn et al. 2005). To ensure that the force used to drill was identical in all cases, the same person operated the drill without exerting any downward force.

To test whether SST and chl a concentration (mg $\mathrm{m}^{-3}$ ) were associated with differences in assemblages among shores, we estimated data from satellite images (NOAA; http://oceancolor.gsfc.nasa.gov). We used standard mapped images (SMIs) of seasonally satellite-derived SST and chl a concentrations from MODIS Aqua for the period May 2008 to May 2009. The images have a spatial resolution of approximately $9.2 \mathrm{~km}$. The global SMI data were subsampled from the region bounded by 33 to $43^{\circ} \mathrm{S}$ and 49 to $65^{\circ} \mathrm{W}$. Satellite data were extracted around $2 \mathrm{~km}$ from the coast.

\section{Data analysis}

To test the hypotheses that mussels will be larger in warmer than in colder shores, and that in the areas of overlap some interspecific competition would be expected, hence, mussel structure will depend on both mussel species, a nested ANOVA was carried out. Brachidontes rodriguezii was analysed including the factor Site (2 levels, random) nested within Shore (2 levels, random). Perumytilus purpuratus was ana- lysed including the factor Site (2 levels, random) nested within Shore (3 levels, random). Heterogeneity of variances was checked by means of Cochran's test, and data were appropriately transformed when necessary (Underwood 1997). For P. purpuratus size, the homogeneity of variances could not be achieved by transformation; data were analysed nonetheless, since ANOVA is robust for departure from this assumption when there are many independent replicates and sizes of samples are equal (Underwood 1997). A cautious approach is recommended when interpreting these results, and only probabilities of $\mathrm{p}<0.01$ were considered.

All mussel length measurements were pooled (4 replicate cores from each of 2 sites) for each shore so that size frequency distributions of mussel populations could be assessed visually. Chi-squared tests were done to compare the size frequency distribution of the 2 mussel species in the 4 shores.

To evaluate the hypothesis that different assemblages of invertebrates would be associated with beds of the different species of mussels, $H^{\prime}, J^{\prime}$, total number of species and mean abundance of invertebrates associated with mussel beds were tested with nested ANOVAs, including the factor Site (2 levels, random) nested within Shore (4 levels, random).

The structures of assemblages were compared among shores and sites using multivariate ANOVA (PERMANOVA) of Bray-Curtis dissimilarities calculated for fourth-root transformed data to meet the assumption of homogeneity of variance. The transformation was applied to reduce the effect of dominant groups in the samples. In some situations in PERMANOVA, there are not enough possible permutations to get a reasonable test. When there is a large number of possible permutations, $p$-values and the Monte Carlo p-value should be very close to one another, but when the number of permutations is low, the $\mathrm{p}$-value associated with the permutation test may be quite different. Because of this limitation, in these cases we used the Monte Carlo p-value (Anderson et al. 2005).

A nonmetric multidimensional scaling ordination (nMDS), using pairwise Bray-Curtis similarities (Bray \& Curtis 1957), was also done to visualize the possible differences in mid-intertidal mussel assemblages and in abundance of intertidal invertebrates associated to mussel matrix at 4 shores.

Canonical correspondence analysis (CCA) was used to elucidate the relationships between the presence/absence of intertidal species and environmental variables (SST and $\mathrm{chl}$ a) operating at the scale of hundreds of kilometres and between the presence/ 


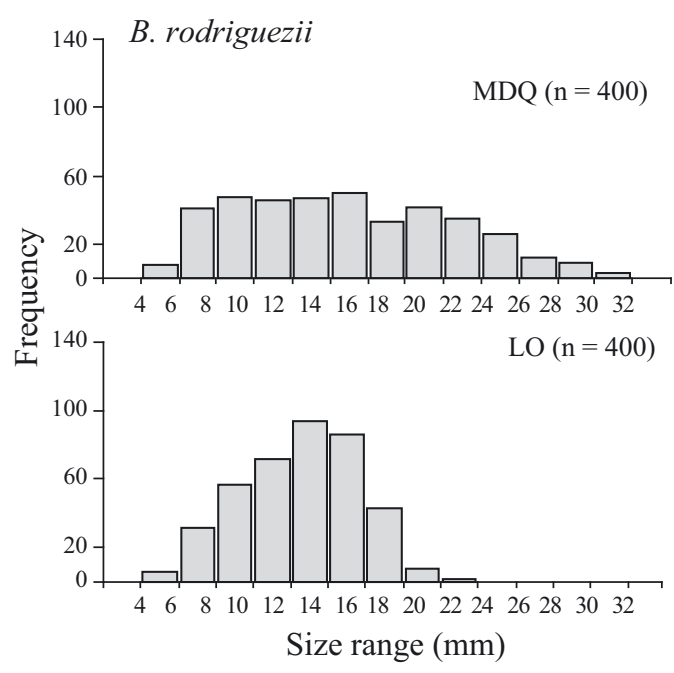

Fig. 3. Brachidontes rodriguezii and Perumytilus purpuratus. Size frequencies ( $>5 \mathrm{~mm}$ ) for populations of both mussels at all sampling locations (see Fig. 1), measured for 50 individuals per replicate core when possible (sites pooled per shore) showing sample size (n)

mean abundance of invertebrates per core associated with mussel beds showed significant differences among shores (Fig. 4d, Table 3). When both mussels species overlapped in distribution, $H^{\prime}$ showed a slight decrease, but significant differences were not found (ANOVA, MS $=0.07, F_{2,29}=0.49, p>0.05$, Fig. 5). The structure of intertidal assemblages differed significantly at both spatial scales (PERMANOVA, Shores, MS = 13670, $F_{3,31}=12.96, \mathrm{p}$ (Monte Carlo) $<0.001$; Sites, MS $=1054, F_{4,31}=2.87, \mathrm{p}$ (permutation) $<0.05$; Fig. 6 ).

\section{Environmental variables}

Sediment retained in mussel beds at MDQ and LO was composed mainly of fine sand (mean phi

Table 2. Brachidontes rodriguezii and Perumytilus purpuratus. Chi-squared test for differences in size frequency distributions of 2 mussel species ( $>5 \mathrm{~mm}$ ) at 4 shores on the Argentinean coast. See Fig. 1 for sites and abbreviations. In all cases, $\mathrm{df}=13, \mathrm{p}<0.001$

\begin{tabular}{|lc|}
\hline Species (sites compared) & $\chi^{2}$ \\
\hline Brachidontes (MDQ-LO) & 743.90 \\
Perumytilus (LO-PS) & 238.92 \\
Perumytilus (LO-PC) & 174.77 \\
Perumytilus (PS-PC) & 613.71 \\
Brachidontes and Perumytilus (LO) & 256.55 \\
\hline
\end{tabular}

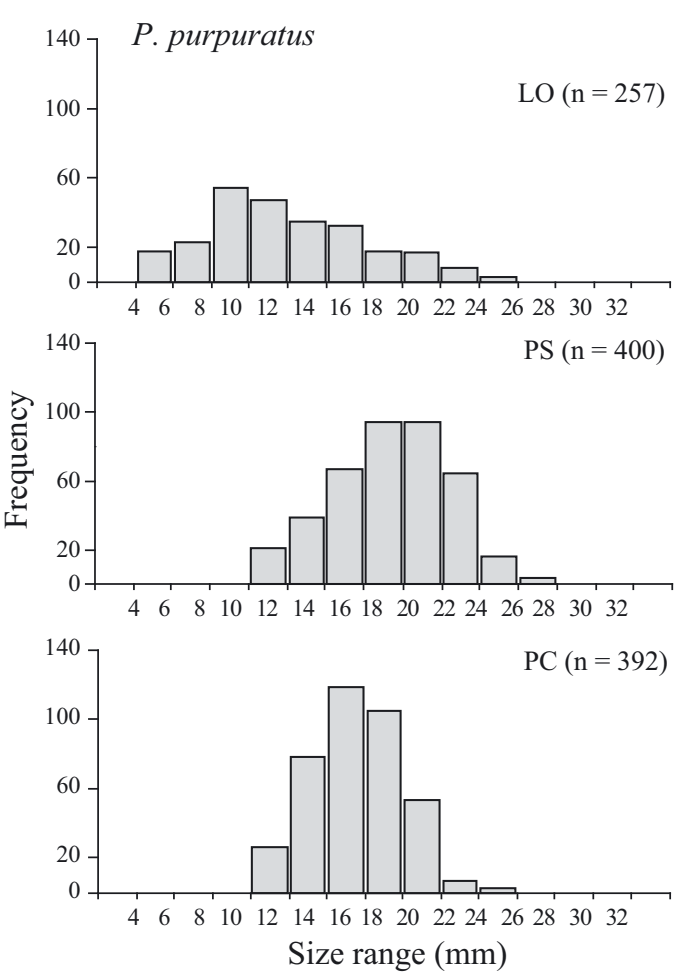

value $=3$ ) and that at PS and PC was mainly coarse sand $(-1)$. The maximal weight of sediment trapped in a mussel core was $6591 \mathrm{~g} \mathrm{~m}^{-2}$ at MDQ and the minimum weight was $122 \mathrm{~g} \mathrm{~m}^{-2}$ at LO. LO had a significantly smaller amount of sediment than the other shores (ANOVA, $\mathrm{MS}=7868, F_{3,31}=15.67, \mathrm{p}<0.05$ ). The hardness of the rock was greater at MDQ (hardness index 4) followed by PS and PC (3), and LO (1).

Maximal mean \pm SE SST from satellite data was $15.76 \pm 3.52^{\circ} \mathrm{C}$ at $\mathrm{MDQ}$, followed by PS, LO and PC (Fig. 7a). The maximal mean chl a from satellite data was $3.78 \pm 1.39 \mathrm{mg} \mathrm{m}^{-3}$ at MDQ, followed by $\mathrm{PC}$, LO and PS (Fig. 7b).

The CCA indicated significant differences between assemblage structure and local factors $(p=0.004)$, although no significant differences were found between assemblage structure and environmental variables $(p=0.842)$. CCA between assemblages and local factors showed that Axis 1 explained $33.14 \%$ of the variation in community structure, and Axes 2 and 3 explained an additional 17.47 and $10.06 \%$, respectively (Table 4a). Latitude was the local factor most closely correlated with Axis 1, followed by rock hardness; Axis 2 was most closely correlated with rock hardness, followed by sediment content. For Axis 3, the magnitude of latitude and rock hardness was weak. Sediment content was the variable most strongly correlated with Axis 3 (Table 5a, Fig. 8a). CCA between assemblages and environmental vari- 


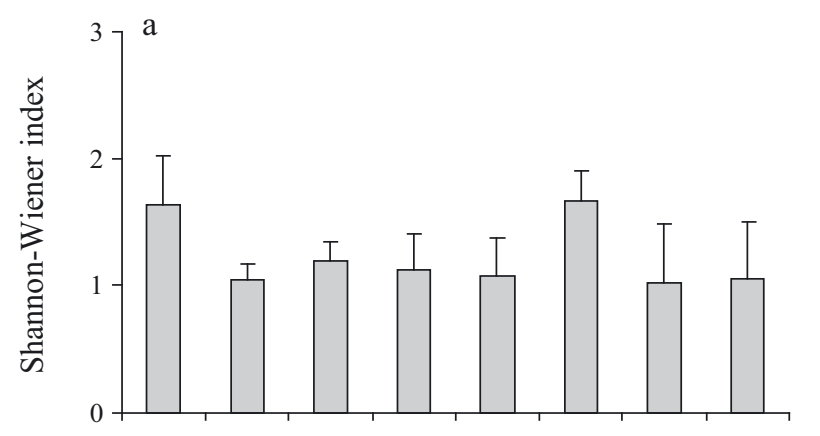

Table 3. Nested ANOVA for Shannon-Wiener diversity index, Pielou's evenness, total number of species and mean abundance of invertebrates at 4 shores on the Argentinean coast. ${ }^{*} \mathrm{p}<0.05,{ }^{* *} \mathrm{p}<0.01$

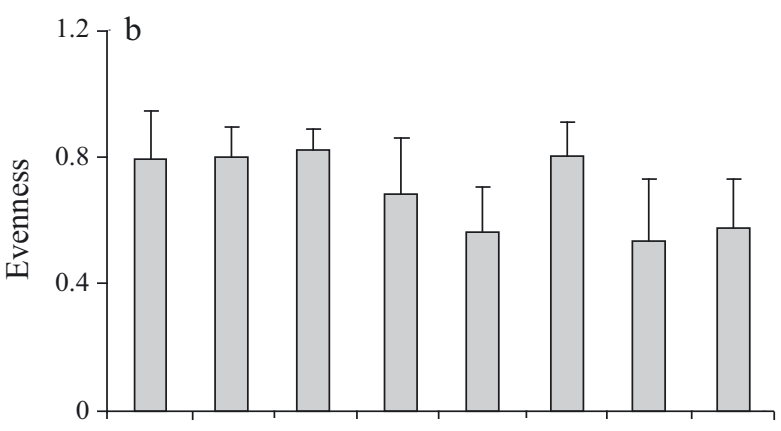

\begin{tabular}{|lccc|}
\hline Source & df & MS & $F$ \\
\hline Shannon-Wiener index & & & \\
Shore & 3 & 0.19 & 0.56 \\
Sites (Sh) & 4 & 0.35 & $3.40^{*}$ \\
Residual & 24 & 0.10 & \\
Evenness & & & \\
Shore & 3 & 0.09 & 2.31 \\
Sites (Sh) & 4 & 0.04 & 1.95 \\
Residual & 24 & 0.02 & \\
Total number of species & & & \\
Shore & 3 & 5.58 & 0.49 \\
Sites (Sh) & 4 & 11.44 & $4.77^{* *}$ \\
Residual & 24 & 2.39 & \\
Mean abundance of invertebrates & & \\
Shore & 3 & 6543.1 & $7.63^{*}$ \\
Sites (Sh) & 4 & 857.2 & 1.19 \\
Residual & 24 & 721.8 & \\
\hline
\end{tabular}
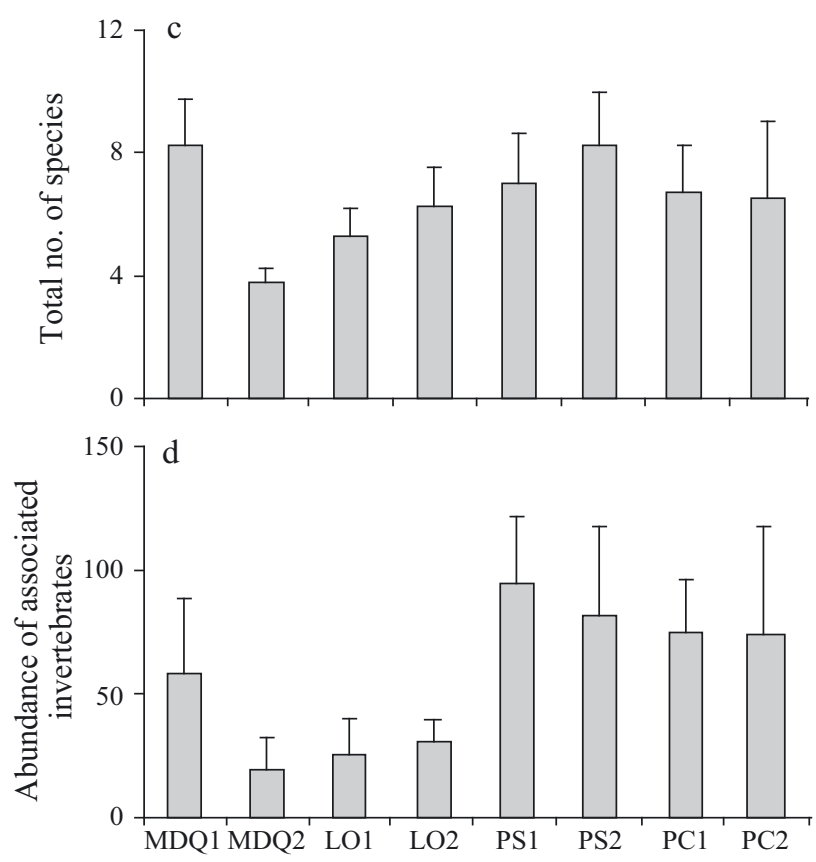

Fig. 4. Brachidontes rodriguezii and Perumytilus purpuratus. Mean $( \pm \mathrm{SE}, \mathrm{n}=4$ replicates) for (a) Shannon-Wiener diversity index, (b) Pielou's evenness, (c) total number of species and (d) abundance of invertebrates associated with mussel beds (see Figs. $1 \& 2$ ). Algae are only included in the total number of species

ables showed that Axis 1 explained $30.86 \%$ of the variation in community structure and Axis 2 explained an additional $5.61 \%$ (Table $4 \mathrm{~b}$ ). SST was the variable most strongly correlated with Axis 1 and chl a with Axis 2 (Table 5b, Fig. 8b).

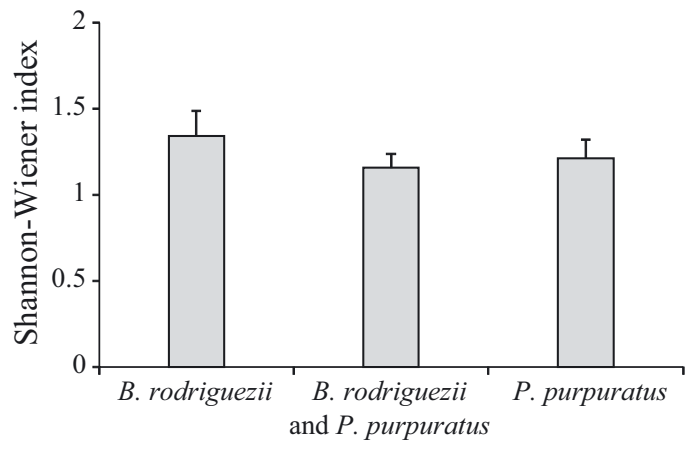

Fig. 5. Brachidontes rodriguezii and Perumytilus purpuratus. Mean $( \pm \mathrm{SE})$ Shannon-Wiener diversity associated with the different mussel species in the study area

Perumytilus purpuratus was strongly correlated with southern latitudes (sites: PS1, PS2, PC1 and PC2), while Brachidontes rodriguezii was correlated with northern latitudes (sites: MDQ1, MDQ2, LO1 and LO2) along Axis 1 (Fig. 8a). Along Axis 2, CCA separated Mytilus edulis, mussel recruits, Idotea baltica, Syllis prolixa, chironomidae larvae, nemerteans and the seaweeds Enteromorpha sp. and Ulva rigida, tending toward northern latitude, lower sediment content and lower rock hardness. The sites LO1 and LO2 were also associated with low sediment content and low rock hardness. Polychaetes (S. gracilis, Harmothoe sp., Cirriformia and unidentified Polychaeta), the isopod Sphaeroma serratum, the amphipod Hyale grandicornis, the limpet Siphonaria lessoni, the barnacle Balanus glandula, little bivalves (Phlyctiderma semiaspera and Lasaea adansoni) and the sea- 


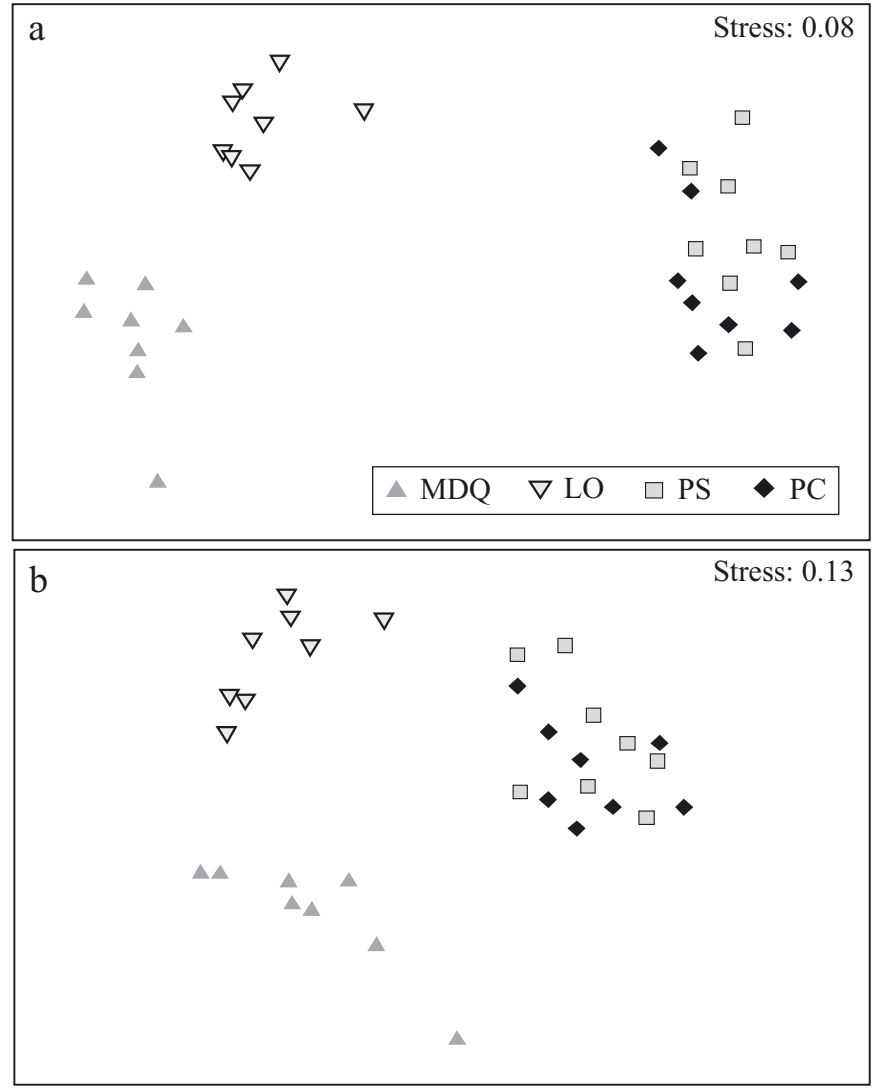

Fig. 6. Two-dimensional nonmetric multidimensional scaling plot ( $\mathrm{n}=8$ sites) comparing (a) species assemblages in mid-intertidal mussel beds (fourth-root transformation) and (b) abundance of intertidal invertebrates associated with mussel beds (square root transformation) at 4 shores (see Fig. 1)

Table 4. Canonical correspondence analysis (CCA) axes summary. (a) Assemblage structure and local factors. (b) Assemblage structure and environmental variables. CV: cumulative variance

\begin{tabular}{|lccc|}
\hline (a) & \multicolumn{3}{c|}{ Canonical axes } \\
& 1 & 2 & 3 \\
\hline Eigenvalues & 0.419 & 0.221 & 0.127 \\
Variance explained (\%) & 33.14 & 17.47 & 10.06 \\
CV explained (\%) & 33.14 & 50.61 & 60.67 \\
(b) & 1 & 2 & \\
\hline Eigenvalues & 0.275 & 0.050 & \\
Variance explained (\%) & 30.86 & 5.610 & \\
CV explained (\%) & 30.86 & 36.47 & \\
\hline
\end{tabular}

weeds Polysiphonia fucoides and Ceramium virgatum showed an opposite pattern, tending toward higher sediment content and higher rock hardness (Fig. 8a). The shore at MDQ was the most strongly correlated
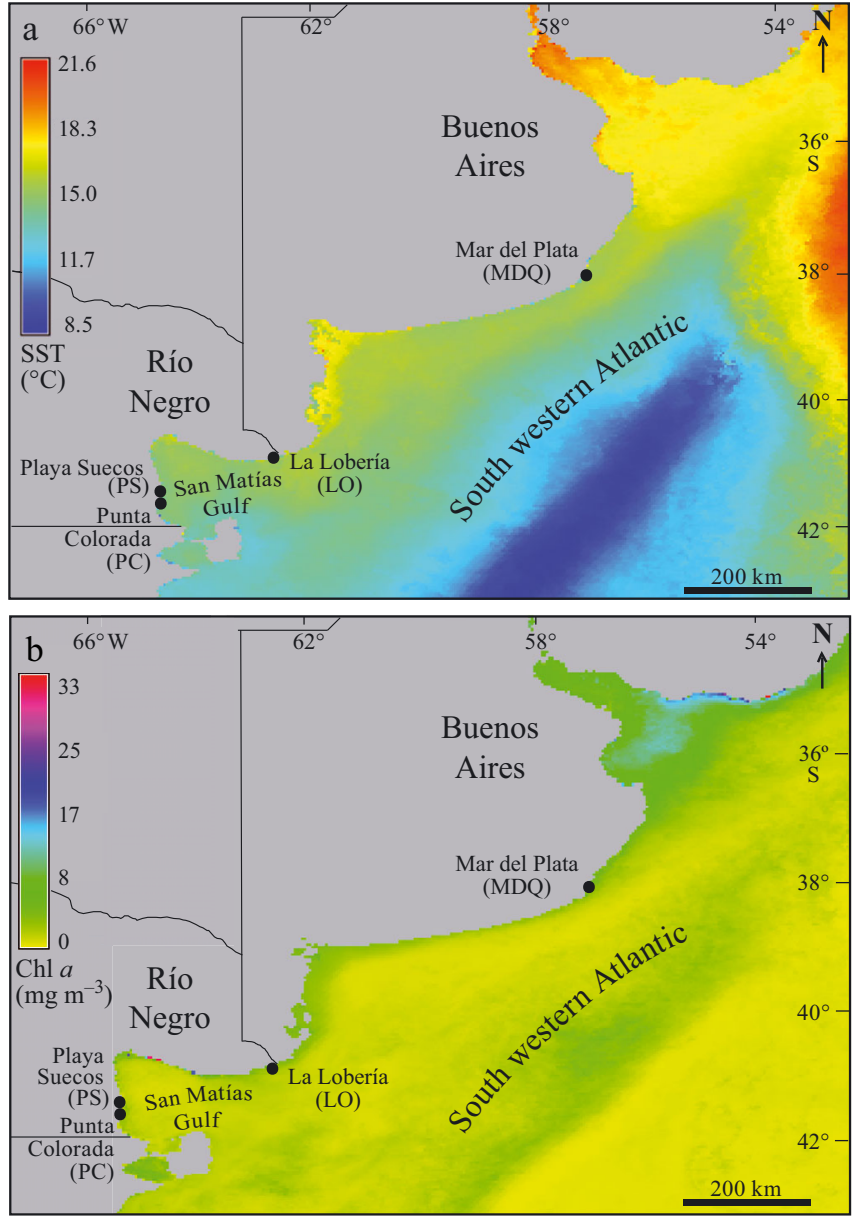

Fig. 7. MODIS Aqua-derived (a) sea surface temperature and (b) surface chl a between May 2008 and May 2009 at the 4 sampling sites

Table 5. Bi-plot scores and coefficients of correlation of (a) local factors and (b) environmental variables in the canonical correspondence analysis. SST: sea surface temperature

\begin{tabular}{|lccc|}
\hline (a) & Axis 1 & Axis 2 & Axis 3 \\
\hline Latitude & -0.969 & 0.192 & 0.153 \\
Sediment content & -0.109 & 0.774 & 0.624 \\
Rock hardness & -0.334 & 0.935 & 0.116 \\
(b) & Axis 1 & Axis 2 & \\
\hline SST & -0.945 & 0.327 & \\
Chl a & -0.811 & -0.585 & \\
\hline
\end{tabular}

with SST and chl a (Fig. 8b). LO, PS and PC shores were associated with low SST and chl a concentration. Species such as $B$. rodriguezii, polychaetes ( $S$. prolixa, S. gracilis and Harmothoe sp.), nemerteas, chironomid 

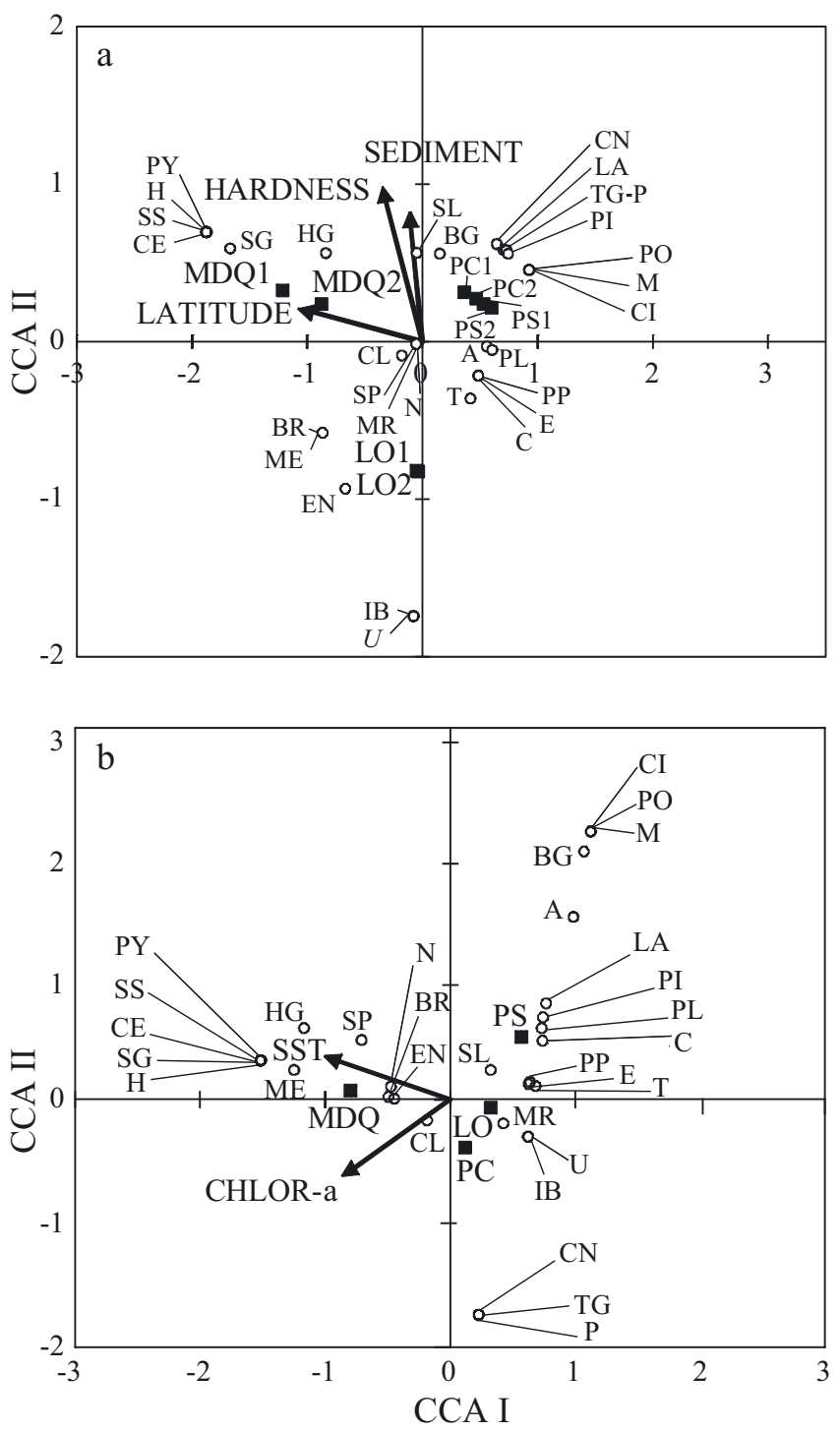

Fig. 8. Canonical correspondence analysis (CCA) ordination diagrams. (a) Biplot representing the presence of species in rocky intertidal (white dots), sites (black squares) and local variables (arrows). (b) Biplot representing the presence of species in rocky intertidal (white dots), shores (black squares) and environmental variables (arrows). SST: sea surface temperature, Chlor-a: chlorophyll a concentration, MDQ: Mar del Plata, LO: La Lobería, PS: Playa los Suecos, PC: Punta Colorada. 1 and 2 correspond to the replicate sites. A: unidentified Amphipoda, BG: Balanus glandula, BR: Brachidontes rodriguezii, CE: Ceramium virgatum, CL: Chironomidae larvae, CI: Cirriformia, CN: unidentified Cnidaria, C: Cyrtograpsus sp., EN: Enteromorpha sp., E: Exospaheroma sp., H: Harmothoe sp., HG: Hyale grandicornis, IB: Idotea baltica, LA: Lasaea adansoni, MR: mussel recruits, M: Myodocopida, ME: Mytilus edulis, N: unidentified Nemertea, PP: Perumytilus purpuratus, P: Phlyctiderma semiaspera, PL: Platynereis sp., PO: Podocopida, PI: unidentified Polychaeta, PY: Polysiphonia fucoides, SL: Siphonaria lessoni, SS: Sphaeroma serratum, SP: Syllis prolixa, SG: Syllis gracilis, T: Tanaidacea, TG: Trophon geversianus, U: Ulva rigida larvae, the amphipod $H$. grandicornis, the isopod $S$. serratum and seaweeds were more correlated with higher SST and higher chl a concentrations.

\section{DISCUSSION}

Three main findings emerged from this study. First, we found a shift in ecosystem engineers along shores; Brachidontes rodriguezii was present at MDQ and LO, and southward it was replaced by Perumytilus purpuratus at PS and PC. At 1 location, both mussel species coexisted, creating particular trends. Second, although both mussel species were similar in morphology and biology, significant differences in the structure of mussel beds occurred between them. Third, each species acted as an ecosystem engineer, modulating the physical conditions of the habitat, and each one was associated with different benthic assemblages.

\section{Mussels}

Along the Buenos Aires coast, Brachidontes rodriguezii is the dominant mid-intertidal species and is replaced towards the south by Perumytilus purpuratus, which dominates Patagonian shores almost completely. In the study area, the 2 mussel species were remarkably dissimilar in density and biomass. $B$. rodriguezii showed differences at a small scale, whereas $P$. purpuratus showed differences at a large scale. Size frequency distributions of both species also differed among shores. For each species, the largest size classes disappeared or became less abundant toward the biogeographic limits of the species (southward toward LO for B. rodriguezii and northward toward LO for P. purpuratus). In South Africa, Cole \& McQuaid (2010) showed the same pattern towards the biogeographic limits for Perna perna and Mytilus galloprovincialis.

Although we hypothesized that parapatric mussels would display different patterns of size structure, body mass and density on the shore where they overlapped (i.e. LO), we did not observe variation in Brachidontes rodriguezii structure, although we did see differences in Perumytilus purpuratus mussel beds. In beds of $P$. purpuratus, density, biomass and size were always smaller at LO. Oceanographic and physical variables such as wave exposure, primary productivity or local meteorological conditions could be modulating such variability. The abundance and growth rates of mussels could also be affected by 
intra- and interspecific competition (Boaventura et al. 2002, Rius \& McQuaid 2006, Firth \& Crowe 2010). When intraspecific competition within the superior competitor is stronger than competition between species, coexistence can occur (Boaventura et al. 2002). In our study, the biomass, density and size of $P$. purpuratus at LO were less than at PS and PC. This could be attributed to competition between the 2 species. For example, the limpet Scutellastra argenvillei was smaller when living in mussel beds than those living on cleared patches (Steffani \& Branch 2005). An increase in density can cause increased mortality, reduced length and reduced weight in species of the same genus (e.g. Patella; Boaventura et al. 2002). In B. rodriguezii, the differences found between sites could be caused by larval behaviour, reflected by variation in recruitment or by mortality after recruitment (Underwood \& Chapman 1996).

We expected mussels to be larger due to faster growth resulting from warmer temperatures at the northern sites. The largest mean size of Perumytilus purpuratus was found at PS, where SST is warmer than in other areas where the species is present. Similarly, at Point Conception, California (USA), Mytilus californianus was found to be larger at southern sites, where warmer water temperature is characteristic (Blanchette \& Gaines 2007). Differences in the sizes of mussels between shores in the present study could be attributed to differential growth, which tends to be greater in warmer waters. An increase in shell size of Brachidontes rodriguezii was observed from colder to warmer shores, although we did not find significant differences (Fig. 2c, Table 1). In our case, these 2 species of mytilids are very similar in morphology and biology. As a result, competition for food or primary space (Dayton 1971, Boaventura et al. 2002) may cause a decrease in density and biomass.

\section{Invertebrate assemblages}

Much descriptive work on rocky intertidal assemblages along the northern Argentinean coast has provided evidence for low biodiversity in these areas (Adami et al. 2004, Bertness et al. 2006, Penchaszadeh et al. 2007). We found 24 species of invertebrate taxa and 4 seaweeds associated with mussel beds, which was similar to results of another study (24 invertebrate taxa and 3 seaweeds, Adami et al. 2004 in Quequén, Argentina) but fewer than reported from some previous studies (e.g. 32 inverte- brate taxa, Scelzo et al. 1996 in artificial substrata at Mar del Plata, Argentina; 41 invertebrate taxa during the NaGISA project in Mar del Plata, M. G. Palomo et al. unpubl. data). In the present study, the most abundant species associated with Brachidontes rodriguezii was the isopod Sphaeroma serratum, while the isopod Exosphaeroma sp. was the most abundant in Perumytilus purpuratus beds.

On intertidal rocky shores, diversity of invertebrates is dependent on foundation species that buffer physical stress (Bertness et al. 2006) and provide refuge (Burrows et al. 2009). The total number of species was lower in northern mussel beds than in southern beds, although significant differences were only found at the site level. In this study, some species were found associated with only 1 species of mussel, e.g. the bivalve Lasaea adansoni with Perumytilus purpuratus, or Mytilus edulis with Brachidontes rodriguezii. $M$. edulis was also found at the low intertidal in PS and PC, and therefore tolerance to stress in the mid-intertidal could be an important factor in determining the presence of some species at different intertidal heights (Cole 2010) and may be dependent on the tidal regime of the coast (Benedetti-Cecchi 2001). In shores such as LO, the presence of both bioengineers could be generating an unstable habitat for associated species, since decreased size or an increase in density could affect larval settlement of associated species or decrease protection against physical conditions, resulting in reduced biodiversity levels as a consequence. Even though no differences were found in the total number of species, biodiversity or evenness among shores, differences were found in invertebrate abundance. Mussels on southern shores provide refuge for invertebrates that are usually unable to survive over bare rock (Bertness et al. 2006). However, the provision of these microhabitats seems to have little effect on the abundance of invertebrates on northern shores, possibly because most species living in mussel matrices can also survive on bare rock, owing to environmental conditions that are not as harsh as in Patagonian shores.

Differences in assemblages between sites are likely to be influenced by physical features of the habitat that create spatial heterogeneity, and as a consequence spatial variation in organisms (Benedetti-Cecchi 2001, Burrows et al. 2009). Furthermore, intertidal organisms with nondispersing larvae present greater small-scale variability (Burrows et al. 2009). As a result, mid-intertidal mussel assemblages showed clear differences among shores due to the foundation species and their structure. 


\section{Environmental variables}

The general latitudinal pattern in species numbers must be related to some climatic factor, or combination of factors, that changes in a consistent manner with latitude. Such factors could include average temperature, annual rainfall and seasonality (Rohde 1992). For example, one factor that affects mussel distribution is the substrate type, since mussels require appropriate substrate to anchor (Harman 1972, Morales et al. 2006). Moreover, nearby bed currents and substrate stability also may affect their distribution (Holland-Bartels 1990, Hardison \& Layzer 2001). We found few associated species correlated with low rock hardness, which could be due to low substrate stability, since low hardness is correlated with higher erosion (Pinn et al. 2005), increasing the susceptibility of mussels to dislodgment and, as consequence generating an unstable habitat for associated fauna.

The number of species found in mussel beds increases with the amount of sediment trapped (Prado \& Castilla 2006). It is possible that accumulation of a large amount of sediment can produce a change in fauna or decreases in the density or diversity of associated animals (Tsuchiya \& Nishihira 1985). In our study, we found a correlation between rock hardness, the amount of sediment retained and the biological assemblage. At LO, the shore with the smallest amount of sediment trapped and the lowest rock hardness index, the diversity of invertebrates was not significantly different from the other shores, but the abundance of invertebrates was lower compared to the other shores. CCA analysis showed that organisms such as annelids or small bivalves and arthropods appear to benefit from large amounts of accumulated sediments, possibly due to biodeposits retained in mussel beds (Thiel \& Ullrich 2002). Hence, sediment accumulation in the mussel matrix was an important factor that modulated species composition along the coast. The strong correlations between assemblage structure and local characteristics suggest that these have a large influence on intertidal community structure patterns along the northern Argentinean coast.

Large-scale processes such as oceanographic conditions influence the presence of species along the coast (Anderson et al. 2005). Most intertidal organisms are faced with the risk of desiccation; therefore, the role of heat stress on organisms associated with habitats engineered by mussels is likely to be an important driving factor (Bertness et al. 2006, Cole 2010). Consequently, differences in the composition of species in mussel beds are likely to be due to large-scale processes, while variation in relative abundance is driven by medium-scale processes. Salinity gradients at large scales and wave exposure gradients at intermediate scales are good predictors for the distribution of mussels (Westerbom et al. 2008). One of the most frequently identified drivers of the distribution of species is temperature, which is related to latitudinal gradients (Gray 2001). Moreover, the abundance of intertidal assemblages has been correlated with SST (Kelaher et al. 2007). Our results did not show a significant correlation between environmental variables and invertebrate assemblages; however, this does not mean that temperature and chl a concentration do not shape community assemblages as the contrary was shown in other studies (Menge et al. 1997, Blanchette et al. 2006). In our case, the non-significant correlation could be attributed to the fact that our shores are not as different in environmental variables as they are in local characteristics or that in situ environmental measurements are needed to complement the satellite data.

The main difference between mussel species was that the population traits of Brachidontes rodriguezii differed significantly among sites (distance between 100 and $500 \mathrm{~m}$ ), while for Perumytilus purpuratus it varied among shores (distance between 4 and $570 \mathrm{~km}$ ). Local factors were good predictors for spatial-scale patterns in the composition of assemblages in the rocky intertidal and in the distribution of mussels along the coast. LO differed from the other shores, with both mussel species having smaller size and lower biomass although only significant for P. purpuratus populations. Competitive interactions between the 2 mussel species may generate populations with different traits and arrangements of individuals. The 2 mytilids coexist over a very short geographic range (LO shore), and the associated fauna was found to differ from the other shores, although it was more similar to MDQ than to PS or PC. A review of the effects of ecosystem engineers on other species suggested that they provide refuge and microhabitats (Gutiérrez et al. 2003). Even though the mussel species are very similar in habitat, occupation and source of food, the assemblages associated with them are very different and the distributions of these associated species and the mussel species are clearly linked with local factors. Our study shows that mussel beds at the edge of their distributional range, despite their low biomass and small individual size, promote and maintain a richly diverse faunal community. The specific species of mussels together with local factors are the main determinants of associated 
assemblages living within mussel matrices. Efforts aimed at investigating ecosystem engineers will benefit from identifying and quantifying the resources affected, including developing and utilizing biologically meaningful metrics of habitat structure (Crooks 2002).

Acknowledgements. This study was funded by the National Council for Scientific Research (CONICET) of Argentina, projects PIP 0732 and PICT 942. We thank C. Herrera for assistance with PRIMER; J. Gutiérrez for field work; M. Brogger, M. Martínez and V. Teso for laboratory work; G. Pastorino for taxonomic identification of molluscs; and B. Lynch. We thank 4 anonymous reviewers for their helpful comments towards improving the manuscript.

\section{LITERATURE CITED}

Adami ML, Tablado A, Lopez Gappa J (2004) Spatial and temporal variability in intertidal assemblages dominated by the mussel Brachidontes rodriguezii (d'Orbigny, 1846). Hydrobiologia 520:49-59

> Anderson MJ, Connell SD, Gillanders BM, Diebel CE, Blom WM, Saunders JE, Landers TJ (2005) Relationships between taxonomic resolution and spatial scales of multivariate variation. J Anim Ecol 74:636-646

- Araujo R, Bárbara I, Sousa-Pinto I, Quintino V (2005) Spatial variability of intertidal rocky shore assemblages in the northwest coast of Portugal. Estuar Coast Shelf Sci 64: 658-670

Badano EI, Marquet PA (2008) Ecosystem engineering affects ecosystem functioning in high-Andean landscapes. Oecologia 155:821-829

$>$ Benedetti-Cecchi L (2001) Variability in abundance of algae and invertebrates at different spatial scales on rocky sea shores. Mar Ecol Prog Ser 215:79-92

- Bertness MD (1989) Intraspecific competition and facilitation in northern acorn barnacles. Ecology 70:257-268

> Bertness MD, Crain CM, Silliman BR, Bazterrica MC, Reyna MV, Hidalgo F, Kongo Farina J (2006) The community structure of western Atlantic Patagonian rocky shores. Ecol Monogr 76:439-460

Blanchette CA, Gaines SD (2007) Distribution, abundance, size and recruitment of the mussel, Mytilus californianus, across a major oceanographic and biogeographic boundary at Point Conception, California, USA. J Exp Mar Biol Ecol 340:268-279

Blanchette CA, Broitman BR, Gaines SD (2006) Intertidal community structure and oceanographic patterns around Santa Cruz Island, CA, USA. Mar Biol 149:689-701

Blanchette CA, Helmuth B, Gaines SD (2007) Spatial patterns of growth in the mussel, Mytilus californianus, across a major oceanographic and biogeographic boundary at Point Conception, California, USA. J Exp Mar Biol Ecol 340:26-48

Boaventura D, Cancela da Fonseca L, Hawkins SJ (2002) Analysis of competitive interactions between the limpets Patella depressa Pennant and Patella vulgata on the northern coast of Portugal. J Exp Mar Biol Ecol 271: 171-188

Borthagaray AI, Carranza A (2007) Mussels as ecosystem engineers: their contribution to species richness in a rocky littoral community. Acta Oecol 31:243-250

Bownes SJ, McQuaid CD (2009) Mechanisms of habitat segregation between an invasive and an indigenous mussel: settlement, post-settlement mortality and recruitment. Mar Biol 156:991-1006

> Bray JR, Curtis JT (1957) An ordination of the upland forest communities of southern Wisconsin. Ecol Monogr 27: 325-349

> Burrows MT, Hughes RN (1989) Natural foraging of the dogwhelk, Nucella lapillus (Linnaeus): the weather and whether to feed. J Molluscan Stud 55:285-295

Burrows MT, Harvey R, Robb L, Poloczanska ES and others (2009) Spatial scales of variance in abundance of intertidal species: effects of region, dispersal mode, and trophic level. Ecology 90:1242-1254

> Cole VJ (2010) Alteration of the configuration of bioengineers affects associated taxa. Mar Ecol Prog Ser 416: $127-136$

> Cole VJ, McQuaid C (2010) Bioengineers and their associated fauna respond differently to the effects of biogeography and upwelling. Ecology 91:3549-3562

> Connell JH (1961) The influence of interspecific competition and other factors on the distribution of the barnacle Chthamalus stellatus. Ecology 42:710-723

> Connolly SR, Roughgarden J (1998) A latitudinal gradient in northeast Pacific intertidal community structure: evidence for an oceanographically based synthesis of marine community theory. Am Nat 151:311-326

> Crooks JA (2002) Characterizing ecosystem-level consequences of biological invasions: the role of ecosystem engineers. Oikos 97:153-166

$>$ Dayton PK (1971) Competition, disturbance, and community organization: the provision and subsequent utilization of space in a rocky intertidal community. Ecol Monogr 41: 351-389

- Elías R, Rivero MS, Vallarino EA (2003) Sewage impact on the composition and distribution of Polychaeta associated to intertidal mussel beds of the Mar del Plata rocky shore, Argentina. Iheringia Ser Zool 93:309-318

Evans JW (1968) The effect of rock hardness and other factors on the shape of the burrow of the rock boring clam Penitella penita. Palaeogeogr Palaeoclimatol Palaeoecol 4:271-278

> Firth LB, Crowe TP (2010) Competition and habitat suitability: small-scale segregation underpins large-scale coexistence of key species on temperate rocky shores. Oecologia 162:163-174

Gray JS (1981) The ecology of marine sediments. Cambridge University Press, Cambridge

> Gray JS (2001) Marine diversity: the paradigms in patterns of species richness examined. Sci Mar 65:41-56

> Gutiérrez JL, Jones CG, Strayer DL, Iribarne OO (2003) Mollusks as ecosystem engineers: the role of shell production in aquatic habitats. Oikos 101:79-90

- Hardison BS, Layzer JB (2001) Relations between complex hydraulics and the localized distribution of mussels in three regulated rivers. Regul Rivers Res Manag 17:77-84

Harman WN (1972) Benthic substrates: their effects on fresh-water Mollusca. Ecology 53:271-277

> Hastings A, Byers JE, Crooks JA, Cuddington K and others (2007) Ecosystem engineering in space and time. Ecol Lett 10:153-164

Holland-Bartels LE (1990) Physical factors and their influence on the mussel fauna of a main channel border habi- 
tat of the Upper Mississippi River. J N Am Benthol Soc 9: 327-335

> Jones CG, Lawton JH, Shachak M (1994) Organisms as ecosystem engineers. Oikos 69:373-386

> Jones CG, Lawton JH, Shachak M (1997) Positive and negative effects of organisms as ecosystem engineers. Ecology 78:1946-1957

- Jones DS (1981) Annual growth increments in shells of Spisliia solidissima record marine temperature variability. Science 211:165-167

Kelaher BP, Castilla JC, Prado L, York P, Schwindt E, Bortolus A (2007) Spatial variation in molluscan assemblages from coralline turfs of Argentinean Patagonia. J Molluscan Stud 73:139-146

Kokot RR, Codignotto JO, Elissondo M (2004) Vulnerabilidad al ascenso del nivel del mar en la costa de la provincia de Río Negro. Rev Asoc Geol Argent 59:477-487

Legendre P, Legendre L (1998) Numerical ecology, 2nd English edn. Elsevier, Amsterdam

Liuzzi MG, López Gappa J (2008) Macrofaunal assemblages associated with coralline turf: species turnover and changes in structure at different spatial scales. Mar Ecol Prog Ser 363:147-156

Mantua NJ, Hare SR (2002) The Pacific Decadal Oscillation. J Oceanogr 58:35-44

Menge BA (1976) Organization of the New England rocky intertidal community: role of predation, competition, and environmental heterogeneity. Ecol Monogr 46:355-393

Menge BA, Daley BA, Wheeler PA, Strub PT (1997) Rocky intertidal oceanography: an association between community structure and nearshore phytoplankton concentration. Limnol Oceanogr 42:57-66

> Morales Y, Weber LJ, Mynett AE, Newton TJ (2006) Effects of substrate and hydrodynamic conditions on the formation of mussel beds in a large river. J N Am Benthol Soc 25:664-676

Murray SN, Ambrose RF, Dethier MN (2002) Methods for performing monitoring, impact, and ecological studies on rocky shores. OCS Study MMS 01-070. US Department of the Interior, Minerals Management Service, Pacific OCS Region, Camarillo, CA

Paine RT (1966) Food web complexity and species diversity. Am Nat 100:65-75

Palomo MG, People J, Chapman MG, Underwood AJ (2007) Separating the effects of physical and biological aspects of mussel beds on their associated assemblages. Mar Ecol Prog Ser 344:131-142

> Peacor SD, Schiesari L, Werner EE (2007) Mechanisms of nonlethal predator effect on cohort size variation: ecological and evolutionary implications. Ecology 88:1536-1547

Editorial responsibility: Riccardo Cattaneo-Vietti, Ancona, Italy
Penchaszadeh PE, Scelzo MA, Palomo MG, Cuevas M, Cledón M (2007) A review of the intertidal rocky shore community at Mar del Plata (Argentina) characterized by the mussel Brachidontes rodriguezii (d'Orbigny, 1846). Publ Seto Mar Biol Lab 8:115-123

Pinn EH, Richardson CA, Thompson RC, Hawkins SJ (2005) Burrow morphology, biometry, age and growth of piddocks (Mollusca: Bivalvia: Pholadidae) on the south coast of England. Mar Biol 147:943-953

Prado L, Castilla JC (2006) The bioengineer Perumytilus purpuratus (Mollusca: Bivalvia) in central Chile: biodiversity, habitat structural complexity and environmental heterogeneity. J Mar Biol Assoc UK 86:417-421

Richardson CA (2001) Molluscs as archives of environmental change. Oceanogr Mar Biol Annu Rev 39:103-164

Rius M, McQuaid CD (2006) Wave action and competitive interaction between the invasive mussel Mytilus galloprovincialis and the indigenous Perna perna in South Africa. Mar Biol 150:69-78

Rohde K (1992) Latitudinal gradients in species diversity: the search for the primary cause. Oikos 65:514-527

Scelzo MA, Elias R, Vallarino EA, Charrier M, Lucero N, Alvarez F (1996) Variación estacional de la estructura comunitaria del bivalvo intermareal Brachidontes rodriguezii (D'Orbigny, 1846) en sustratos artificiales (Mar del Plata, Argentina). Neritica 10:87-102

> Steffani CN, Branch GM (2005) Mechanisms and consequences of competition between an alien mussel, Mytilus galloprovincialis, and an indigenous limpet, Scutellastra argenvillei. J Exp Mar Biol Ecol 317:127-142

Thiel M, Ullrich N (2002) Hard rock versus soft bottom: the fauna associated with intertidal mussel beds on hard bottoms along the coast of Chile, and considerations on the functional role of mussel beds. Helgol Mar Res 56:21-30

Tsuchiya M, Nishihira M (1985) Islands of Mytilus as a habitat for small intertidal animals: effect of island size on community structure. Mar Ecol Prog Ser 25:71-81

Underwood AJ (1997) Experiments in ecology: their logistical design and interpretation using analysis of variance. Cambridge University Press, Cambridge

- Underwood AJ (2000) Experimental ecology of rocky intertidal habitats: What are we learning? J Exp Mar Biol Ecol 250:51-76

Underwood AJ, Chapman MG (1996) Scales of spatial patterns of distribution of intertidal invertebrates. Oecologia 107:212-224

> Westerbom M, Mustonen O, Kilpi M (2008) Distribution of a marginal population of Mytilus edulis: responses to biotic and abiotic processes at different spatial scales. Mar Biol 153:1153-1164

Submitted: August 13, 2012; Accepted: January 23, 2013 Proofs received from author(s): February 25, 2013 